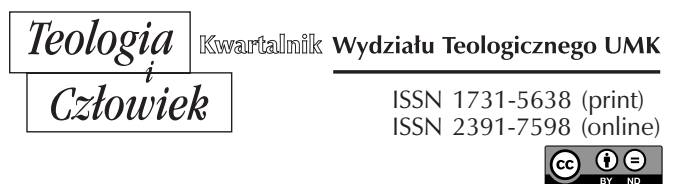

51(2020)3, ss. $29-47$

\title{
CZY JEDYNY BÓG MOŻE MIEĆ SYNA? STUDIUM OSOBOWOŚCl BOGA JAHWE W KONTEKŚCIE IDEI WCIELENIA W MYŚLI HAROLDA BLOOMA
}

DOI: http://dx.doi.org/10.12775/TiCz.2020.037

Streszczenie. Tora jest nie tylko księgą fundamentalną dla dwóch religii monoteistycznych, lecz również inspirującym kolejne pokolenia dziełem literackim. W tej drugiej perspektywie bada Biblię Harold Bloom, przedstawiając w swoich pracach niezwykłą charakterystykę Boga Jahwe, który jawi się w nich jako postać barwna, pełna ludzkich namiętności i życiowej energii, kapryśna, zmienna, czyli zdecydowanie odbiegająca od tej znanej z ortodoksyjnej teologii, zarówno żydowskiej, jak i chrześcijańskiej. Artykuł rozważa kwestię związków Jahwe z Jezusem Chrystusem oraz kategorię Wcielenia w świetle badań estetycznych i literackich Blooma.

Słowa kluczowe: Harold Bloom; Tora; Księga J; Wcielenie.

Abstract. TCan the Only God Have a Son? A Study of the Personality of God Yahweh in Context of the Idea of the Incarnation in Harold Bloom's thought. The Torah is not only a fundamental book for two monotheistic religions, but also an inspirational literary work for successive generations. Harlod Bloom researches the Bible in this second perspective. He presents in his works very interesting psychological profile of God Yahweh, who appears in them as a colorful figure, full of human passions and life energy, capricious, changeable, which is primarily different from the orthodox theology, both Jewish and Christian. The paper considers the connection of this Yahweh with Jesus Christ and the category of the Incarnation in the light of Blook's aesthetic and literary research.

Keywords: Harold Bloom; Torah; The Book of J; Incarnation. 
Czy można napisać biografię Boga? Zbadać jego charakter, wskazać kluczowe momenty życia, prześledzić czyny, ukazać motywacje, przeanalizować przyjacielskie i rodzinne relacje? Problem ten wydaje się absurdalny nawet $\mathrm{z}$ religijnego punktu widzenia, gdzie od Klemensa Aleksandryjskiego i Pseudo-Dionizego Areopagity dominuje podejście apofatyczne. Niemniej, próby takie były i są wciąż podejmowane ${ }^{1}$. O ile jednak bazujące na Ewangeliach próby opisu dziejów historycznego Jezusa, abstrahujące przecież od domniemanej boskości, wydają się do pewnego stopnia zasadne, o tyle pomysł biografii Boga Starego Testamentu jawi się jako wyjątkowo kontrowersyjny. Mimo oczywistych trudności również przykłady takich dzieł odnajdujemy - wystarczy wspomnieć Odpowiedź Hiobowi Carla Gustava Junga ${ }^{2}$, czy znaną na całym świecie pracę Jacka Milesa - Bóg. Biografia ${ }^{3}$. Chciałbym w moim tekście przeanalizować podobną próbę, dokonaną przez Harolda Blooma, znanego na całym świecie krytyka literackiego, który w dwóch swoich książkach Księga J oraz Jesus and Yahweh. The names divine podejmuje się właśnie takiego karkołomnego zadania. Perspektywa i cel Blooma nie jest jednak ani teologiczny ani tym bardziej historyczny. Bóg interesuje go przede wszystkim jako postać literacka. Jego analiza jest zatem próbą przedstawienia charakteru i dziejów postaci literackiej, której poziom głębi i skomplikowania charakteru przekracza nawet złożoność postaci szekspirowskich ${ }^{4}$.

W tekście przedstawiam krótko Bloomowską interpretację wybranych fragmentów Biblii skupiając się na jednym tylko jej aspekcie - przedstawieniu „rodzinnych relacji” Jahwe i Jezusa. Chciałbym wraz z Bloomem postawić pytanie o związki literackiego Jahwe z Jezusem Chrystusem ukazanym w Nowym Testamencie, stawiając pytanie o możliwość Wcielenia w tym kontekście.

1 Benedykt XVI, Jezus z Nazaretu: od wjazdu do Jerozolimy do zmartwychwstania, tłum. W. Szymona, Kraków 2019; tenże, Jezus z Nazaretu: od chrztu w Jordanie do Przemienienia, tłum. W. Szymona, Kraków 2017; R.L. Bruckberger, Dzieje Jezusa Chrystusa, tłum. M. Ponińska, Warszawa 1970.

2 C.G. Jung, Odpowiedź Hiobowi, tłum. J. Prokopiuk, Warszawa 1995.

${ }^{3}$ J. Miles, Bóg: biografia, tłum. A. Grabowski, Warszawa 1998.

${ }^{4} \mathrm{H}$. Bloom, A. Bielik-Robson, Judeochrześcijaństwo to mit, „Dziennik - wydanie internetowe", 5.11.2007, (https://wiadomosci.dziennik.pl/wydarzenia/artykuly/183928,judeochrzescijanstwo-to-mit.html (dostęp 8.05.2019 r.)). 


\section{KIM JEST JAHWE?}

Swoje rozważania o Bogu w Biblii opiera Bloom na przekonaniu, że Biblia nie jest jedną księgą, ale zbiorem wielu, pisanych w różnych czasach i przez wielu autorów tekstów, które zostały zebrane w kanon Tanach być może nawet dopiero w I wieku n.e. ${ }^{5}$ i kanon Biblii Chrześcijańskiej w IV wieku'. Wynika z tego jego zdaniem, że zarówno z perspektywy chrześcijańskiej, jak i żydowskiej daremnie poszukuje się w Torze, Prorokach czy Nowym Testamencie jednej, spójnej idei bóstwa. Biblia zawiera zatem wiele różnorodnych przedstawień Boga Izraela i nazywa Go wieloma imionami: Jahwe, Elohim, Adonai, Przedwieczny z Księgi Daniela, czy Oblubieniec z Pieśni nad Pieśniami. Każde z tych określeń wiąże się z inną wizją Boga. Nie sposób w tym miejscu wszystkich ich omówić, tym bardziej nie jest możliwe dokonanie syntezy tych przedstawień w postaci jednego pojęcia Boga. Skupię się zatem na najważniejszym dla Blooma, a jednocześnie historycznie najstarszym ujęciu Jahwe z Księgi J, czyli, mówiąc w pewnym uproszczeniu, tej części Tory, w której Bóg nazywany jest imieniem Jahwe ${ }^{7}$.

${ }^{5}$ P. Johnson, A history of the Jews, New York 2006, s. 90. R.C. Newman, The Council of Jamnia and the Old Testament Canon, „Westminster Theological Journal”, t. 38, nr 4(1976) nr 38, s. 323.

${ }^{6}$ B. M. Metzger, The canon of the New Testament: its origin, development, and significance, Oxford-New York 1987, s. 238. Główny korpus Nowego Testemantu ukształtował się znacznie wcześniej, już Ireneusz z Lyony pod koniec II w. daje świadectwo uznawania czterech Ewangelii, niemal całego korpusu Pawłowego i Objawienia, niemniej drobne spory trwały znacznie dłużej. M.J. Kruger, The Question of Canon: Challenging the Status Quo in the New Testament Debate, Downers Grove 2013, s. 156nn, 202n.

7 Zgodnie z teorią źródeł Pięcioksiąg stanowi kompilację przynajmniej kilku tekstów, które powstały w różnych czasach i miały różnych autorów. Pewnym podstawowym kryterium odróżniania tych tradycji jest obok stylu, słownictwa, danych historycznych itp. imię, którym autor określa Boga. Najstarsza część, posługująca się imieniem Jahwe została nazwana przez Blooma Księgą J. Należy jednak wyraźnie podkreślić, że niemal żaden z badaczy Biblii tak odważnie jak Bloom nie określił nigdy zakresu tej części Pięcioksięgu. Bloom nie podaje jasnych, naukowych kryteriów, którymi posłużył się przy swoim wyborze, a najczęściej odwołuje się po prostu do swego literackiego wyczucia H. Bloom, Ksiega J, tłum. B. Baran, Warszawa 2018, s. 37. 
Bloom traktuje ten fragment Tory jako samodzielne dzieło literackie, którego rekonstrukcji dokonał w swojej Księdze $J^{8}$. Autorstwo tekstu przypisuje, nieco arbitralnie, kobiecie, żyjącej jego zdaniem na dworze Roboama, syna króla Salomona około X w. p.n.e. ${ }^{9}$

Przeanalizujmy kilka „klisz” z życia Jahwe, które pokazuje nam J w swoim tekście. Otwiera ona i zamyka swą opowieść o Jahwe obrazem Boga grzebiącego w ziemi - jej dzieło rozpoczyna się ulepieniem z gliny pierwszego człowieka, kończy - pogrzebaniem zmarłego Mojżesza ${ }^{10}$. Pomiędzy tymi wydarzeniami, które jak klamra spinają jej opowieść, J buduje złożoną, wieloaspektowa charakterystykę Jahwe - osobowości niestabilnej, chaotycznej, pod każdym możliwym względem niedojrzałej, kapryśnej i niebezpiecznej w swej wszechmocy, która gorąco i zazdrośnie kocha, ale też bez opamiętania nienawidzi, która potrafi znudzić się i porzucić swoich wybrańców, która sama dopiero dojrzewa psychicznie. Najogólniej mówiąc, cechy Jahwe są antytetyczne - $\mathrm{z}$ jednej strony jawi się on jako stwórca, a z drugiej niszczyciel ${ }^{11}$.

Do dzieł stwarzania można bezwzględnie zaliczyć historię o ulepieniu z gliny Adama. Efektem dziecięcej zabawy Jahwe, jego bezmyślnej igraszki, jest stworzenie żywego człowieka ${ }^{12}$. Mężczyzna powstaje niejako przypadkiem, z Boskiego kaprysu, z całą pewnością nie jako zaplanowane i przemyślane dzieło. Jahwe, stwarzając Adama, jest niezdarny, nieco chaotyczny, można by rzec „uroczo, dziecięco nieudolny”. Jednakże prędko się uczy. Kolejny akt stworzenia - stworzenie kobiety z materii o wiele doskonalszej niż glina, już ożywionej substancji, odbywa się sprawniej, w sposób bardziej uroczysty i doniosły. Chciałoby się powiedzieć - oto Stwórca $\mathrm{z}$ prawdziwego zdarzenia ${ }^{13}$.

${ }^{8}$ W artykule, pisząc o książce Blooma, będę używał zapisu Księga J. Odwołując się do części Tory autorstwa J będę stosował zapis bez kursywy.

9 Tamże, s. 59. Problem tożsamości J jest tematem na osobny artykuł. W tym miejscu wspomnę jedynie, że Bloom swoje przypuszczenia opiera przede wszystkim na sposobie opisu wydarzeń związanych z kobietami w Biblii, ironicznym podejściem do mężczyzn, wrażliwością na sprawy związane z macierzyństwem, kobiecością itp. Tamże, s. 46, 51.

10 Tamże, s. 303.

11 J. Miles, Bóg, s. 35, 49n.

${ }^{12}$ H. Bloom, Księga J, s. 54.

13 Tamże, s. 187n. Czułość i staranność, którą przejawia tu Jahwe, stwarzając 
Co warto w tym miejscu podkreślić - natura człowieka w Biblii, zwłaszcza w Księdze J, nie jest dualistyczna, nie ma tu nawet mowy o złożeniu z ciała i duszy. Stworzenie człowieka nie może być rozumiane jako tchnięcie duszy w nieożywioną materię. Glina, z której został ulepiony Adam, nie ma przypominać marnego prochu ziemi, który jest ludzkim początkiem i przeznaczeniem, ale stanowi hołd dla ziemi i samego rodzaju ludzkiego. Stworzenie, ani człowiek ani świat, nie może być opisywane w kategoriach upadku. Jak powie Bloom, J jest „najbardziej monistyczna ze wszystkich autorów” Bibliii ${ }^{14}$. Początków metafizycznych podziałów na duszę i ciało, przyrodę i umysł, a nawet dobro i zło w jej tekście nie należy się dopatrywać. Jest to idea grecka, obca Biblii, co potwierdza tezę Blooma o fałszywości mitu judeochrześcijaństwa. Nie znajdziemy również w Księdze J śladów dualizmu etycznego. Monizm J widoczny jest również w charakterystyce rajskiego „czarującego” kusiciela - Węża, którego dopiero wtórnie przekształci się w Szatana, zwodziciela rodzaju ludzkiego. Nie ma powodu, odwołując się do księgi J, przypisywać Wężowi złej woli. Jego zamiary - otwarcie człowiekowi oczu na Dobro i Zło, są zasadniczo zbieżne z zamiarami Jahwe, który arbitralnie atrybut ten przydał Aniołom, a odmówił go ludzkości.

Jahwe ukazany przez J bynajmniej nie swata kobiety Adamowi. Aluzja do stworzenia $\mathrm{z}$ żebra nie ma w żaden sposób umniejszyć kobiety, wręcz przeciwnie, ma ukazać jej wyjątkowość ${ }^{15}$. J podkreśla równość i konieczność wzajemnej pomocy stworzonych kobiety i mężczyzny. Nie ma w jej księdze mowy o żadnym podporządkowaniu kobiety, choć subtelność hebrajskiego tekstu zwykle umyka tłumaczom ${ }^{16}$.

Dzieło Stworzenia i następujące zaraz po nim wygnanie pierwszych ludzi to pierwsze akty, za pomocą których J zarysowuje skomplikowaną osobowość swojego bohatera. Jahwe w działaniu jest nieco chaotyczny i przejawia skłonność do eksperymentowania. Jednocześnie nie jest metodyczny i nie trzyma się wcale raz obranego schematu. Jest impulsywny, i niemal rozczulająco nieudolny wychowawczo.

kobietę, złożoność tego opisu, zupełnie niespotykana wśród ówczesnych autorów, skłoniły, między innymi, Blooma do poglądu, że J jest kobietą.

\footnotetext{
14 Tamże, s. 185.

15 Tamże, s. 190.

16 Tamże. s. 188.
} 
Stwórca Jahwe dopełnia się w dziele J z Niszczycielem. Stosunek samego Jahwe do owoców własnej pracy jest bowiem co najmniej ambiwalentny. Księga Rodzaju pokazuje, że pierwsi ludzie, a także kolejne pokolenia są dla niego rozczarowaniem, ale, gdy Stwórca miewa swój "gorszy dzień", to nie tylko istoty świadome, ale i ptaki, drzewa, zwierzęta wydają mu się obmierzłe ${ }^{17}$. W przypływie złego humoru karze świat potopem, ocalając jedynie nieliczne spośród swych stworzeń. W innym miejscu czytamy, jak Jahwe schodzi na kontrolę Wieży Babel, niczym nieubłagany inspektor budowlany - niezadowolony i zazdrosny wprowadza pomieszanie języków. Symbol Wieży Babel zawiera w sobie niejako tezę i antytezę - element stwórczy i zasadę upadku. Jednakże to człowiek jest tym razem twórcą - Jahwe tu, jak i wiele razy później, objawi swoje oblicze niszczyciela, mąciwody i urwisa ${ }^{18}$. W podobnej roli widzimy Jahwe podczas zniszczenia Sodomy, poprzedzonej targami o „dziesięciu sprawiedliwych” z próbującym ratować mieszkańców miasta Abramem ${ }^{19}$ oraz podczas największej próby charakteru Jahwe, która miała miejsce podczas ucieczki Izraelitów z Egiptu i zawarcia Przymierza z ludem za pośrednictwem Mojżesza, kiedy to Jahwe poraził swym gniewem czcicieli Złotego Cielca. Gniew Boga jednak szybko mija. Nie ważąc na własne klątwy, składa kolejne, niepewne poręki wiecznego sojuszu ${ }^{20}$.

Szczególnie ta ostatnia historia ukazuje ciekawe cechy usposobienia Jahwe i wskazuje, co podkreśla również Miles, na osobowy rozwój Boga, co wydaje się szczególnie paradoksalne. Kryzysową próbą charakteru Jahwe okaże się realizacja jego planu wyprowadzenia Izraelitów z Egiptu. Nie jest to już jednorazowa przygoda, prowadzenie wybrańca, który podporządkowuje się we wszystkim, ale długotrwałe i wymagające konsekwencji przewodzenie irytującemu i krnąbrnemu motłochowi. W drodze do Ziemi Obiecanej stopniowo ujawniają się ambiwalentne cechy Boskiego charakteru. Ewidentnie okazuje zniecierpliwienie, $\mathrm{z}$ trudem znosi niewdzięczność ludu. Walczy z pokusą, by uwolnionych z Egiptu pozabijać i zacząć wszystko od nowa, z jakimś bardziej posłusznym ludem. Powstrzymuje

\footnotetext{
17 Tamże, s. 202.

18 Tamże, s. 205.

19 Tamże, s. 221-223.

20 Tamże, s. 202.
} 
swe gniewne zapędy, nie z litości do ludzi, ale z troski o własne dobre imię - wszak czym innym jest uśmiercić pierworodnych Egipcjan, a czym innym zwrócić się przeciw własnemu ludowi, który co by nie powiedzieć, na siłę wyswobodziło się spod panowania faraona ${ }^{21}$.

Co wielce interesujące, Jahwe wykazuje temperament introwertyczny. Znacznie komplikuje on relacje, w które Bóg wchodzi z kolejnymi pokoleniami Ludu Wybranego. O ile w kontaktach z Abramem, czy Jakubem Jahwe jest dość bezpośredni i otwarty, to w momencie gdy Lud się rozrasta, Jahwe się wycofuje, woli sterować poczynaniami ludzi z daleka, nie wchodząc w bezpośrednią interakcję. Rozmawia z Izraelitami tylko za pośrednictwem Mojżesza i wyraźnie ogranicza do minimum kontakty $\mathrm{z}$ tłumem, który uznaje za obmierzły ${ }^{22}$.

Znosząc narzekania i niewdzięczność mas ${ }^{23}$ i hamując gniew, Jahwe na pustyni powoli zbliża się do nerwowego załamania. Kryzysy nerwowe Boga są jednak o wiele poważniejsze niż ludzkie kryzysy. Bezpośrednio po teofanii pod Synajem (19 i 24 rozdział Księgi Wyjścia), kiedy Bóg otwiera się na innych - objawia się i ucztuje na szczycie góry z siedemdziesięciu starszymi Izraela, co tego introwertycznego Boga musiało wiele kosztować, lud odwraca się od Niego i kieruje swe nadzieje ku odlanemu ze złota cielcowi. Jahwe, po uroczystym geście otwarcia się na starszych Ludu, czuje się szczególnie dotknięty. Jego dar został wzgardzony i zbezczeszczony. Wpada w morderczy gniew, który udaje się nieco uśmierzyć Mojżeszowi, argumentującemu, że wygubienie Żydów na pustyni z pewnością uraduje Egipcjan, którzy będą naigrawać się z naiwności Ludu Wybranego i ich kapryśnego $\mathrm{Boga}^{24}$.

Kryzys ten przyczynia się do psychicznego dojrzewania zdradzonego Jahwe, który w jego wyniku zyskuje samowiedzę, określając się odtąd Bogiem zazdrosnym (namiętnym, pełnym gorliwości). Jego boska, niewspółmierna do ludzkiej zaborczość, na zawsze określi charakter jego

21 Tamże, s. 280.

22 Tamże.

${ }^{23}$ Jak zauważa Bloom, niewdzięczność ta w Księdze J ma swoje uzasadnienie - lud bowiem w trakcie swojej wędrówki dochodzi do przekonania, że Boże błogosławieństwo polega na tym, że całe swoje życie spędzą na pustyni, prowadzeni przez na wpół obłąkanego proroka.

24 Tamże, s. 292. 
nowej relacji z Ludem Wybranym. Nie podchodzi już do ludzi tak emocjonalnie, unika przywiązywania się, ale i wymierzania kar pod wpływem impulsu. Kolejne objawy niewierności zdaje się przyjmować z przerażającym chłodem i cynizmem. Działa bardziej racjonalnie i konsekwentnie skazując lud na gorszą od śmierci wędrówkę po pustyni, ale nie rozciągając kary na kolejne pokolenia (Lb 14,285). O ile jednak skutkiem ludzkich kryzysów jest zmiana indywidualnych życiowych dróg, tak w przypadku kryzysu Boskiego i skutki są absolutne - następuje kosmiczne zerwanie z rzeczywistością baśniową i powstanie rzeczywistości historycznej ${ }^{26}$. Wydaje się, że Bloom chce nam w ten sposób powiedzieć, że J próbuje pokazać jak losy kilku baśniowych herosów stanowiące założycielską legendę przekształcają się w dzieje narodu i dają początek historii. Dokonuje się to dzięki rozciągnięciu Błogosławieństwa Jahwe z jednostek na cały, anonimowy lud. W tle tego kosmicznego przejścia widzimy duchowy kryzys Boga, skąpego w obdarowywaniu nawet swoich wybranych, który musi dokonać radykalnych zmian we własnym usposobieniu.

W powyższych rozważaniach udało mi się wskazać zaledwie kilka wybranych aspektów Boskiej osobowości. Nie mogę niestety szerzej ich omówić, dlatego, krótko podsumowując, można powiedzieć, że J w swojej księdze daje nam obraz Jahwe urwisa-wojownika - bądź to skrajnie radosnego, bądź wściekłego, budującego, lub burzącego swoje dzieła, wpadającego w manię lub melancholię, o osobowości introwertycznej, dobrze czującego się w wąskim gronie najbliższych. Obraz osoby, która nie radzi sobie $\mathrm{z}$ własną wszechmocą, która po swoich trudach potrzebuje odpocząć, która łatwo porzuca postawione sobie wcześniej cele, łatwo traci zainteresowanie innymi ludźmi, ale jest ślepo lojalna wobec swoich ulubieńców, która często bywa głodna ${ }^{27}$ i uwielbia pikniki na świeżym powietrzu ${ }^{28}$.

Czytającemu Bloomowską charakterystykę Boga nasuwa się wniosek, że jest ona powieleniem jednego z najstarszych grzechów teologii, mianowicie antropomorfizacji. Bloom, zdając sobie $\mathrm{z}$ tego sprawę, powie,

${ }^{25}$ Za każdym razem, odwołując się do Biblii, korzystam z wydania Pisma Świętego Starego i Nowego testamentu. W przekładzie z języków oryginalnych, Poznań 1991.

${ }^{26}$ Tamże s. 339.

27 Tenże, Jesus and Yahweh: the names divine, New York 2005, s. 196.

28 Tenże, Ksiega J, s. 218, 280. 
że negatywna teologia w zasadzie w ogóle go nie zajmuje, gdyż teologia zwykle jest po prostu bardzo kiepską literaturą ${ }^{29}$, że szuka Boga, który jest właśnie „ludzki, arcyludzki”, gdyż nie „boskość Boga” go interesuje, ale jego arcyludzki charakter. Biblijny Jahwe jest jego zdaniem, mimo, a właściwie dzięki antropomorficznym cechom, które mu przysługują, najbardziej perswazyjną reprezentacją transcendentnej inności, jaką można odnaleźć we wszystkich religiach ${ }^{30}$. Zawiera w sobie w jedności wszystkie najważniejsze ludzkie cechy, które nawet sam uwielbiany przez Blooma Szekspir zmuszony był „rozdzielić” na szereg postaci - od Hamleta, przez Leara, Prospera, aż do Falstaffa ${ }^{31}$.

Bloom w swojej charakterystyce Jahwe próbuje przekonać swojego czytelnika, iż wcielenie tego Boga byłoby dla ludzkości katastrofą. Czy zatem Jahwe, może być $\mathrm{w}$ jakiś sposób powiązany z rabinem $\mathrm{z}$ Nazaretu - Jezusem Chrystusem Wcielonym Bogiem? Aby podjąć próbę odpowiedzi na to pytanie należy pogłębić obraz osobowości Jahwe, analizując jego „życie społeczne”, zwłaszcza to, co można w pewnym sensie określić więziami rodzinnymi oraz umieścić w tym kontekście najbardziej interesującego spośród „krewnych Jahwe” - Jezusa Chrystusa.

\section{JAHWE OJCEM?}

Jahwe w Biblii jest ukazany jako bliski człowiekowi. Co kilka pokoleń, częściej lub rzadziej, nawiązuje bezpośrednią, bliską relację z jakimś wybrańcem. Wydaje się, co sugeruje sama Biblia, że można te relacje nazwać przyjacielskimi, a analizując więź Jahwe z Adamem i Ewą, nawet rodzinnymi. Relacje przyjacielskie i „rodzinne” Jahwe są z jednej strony bardzo intymne i pełne czułości, z drugiej zaś burzliwe i tragiczne. Bloom naświetla je nieco w swojej Księdze J, w której przedstawia „rodzinny romans, który nieoczekiwanie przeradza się $\mathrm{w}$ «rodzinną

29 Tenże, Jesus and Yahweh, s. 98.

30 Tamże, s. 170. Interesujące jest to, że obrona „antropomorfizmu” u Blooma koresponduje ze współczesnym, teologicznym ujęciem, które podkreśla, że nie mówimy antropomorficznie o Bogu, ale raczej teomorficznie o człowieku. H. Thielicke, Der Evangelische Glaube, Bd. 2: Gotteslehre und Christologie, Tübingen 1973, s. 8.

31 H. Bloom, Ksiega J, s. 348. 
tragedię» $^{32}$, jak rozumie mit Upadku Pierwszych Ludzi. Właściwie jednak w przypadku Księgi J nie sposób mówić o „upadku”. Jej autorce nie chodzi bowiem o nieposłuszeństwo wobec boskich wyroków, grzech pierworodny, czy zniszczenie pierwotnie doskonałej ludzkiej natury, lecz o tragiczne w skutkach nieporozumienie, prowadzące do bolesnej dla wszystkich bohaterów opowieści separacji - wypędzenia $\mathrm{z}$ rodzinnego domu, które nierozerwalnie wiąże się z przyspieszonym z konieczności dojrzewaniem młodych i „syndromem pustego gniazda” dotykającym Jahwe. J pokazuje, że Jahwe bynajmniej nie jest ojcem doskonałym, który wystrzega się błędów wychowawczych. Po spożyciu owocu z drzewa poznania Dobra i Zła, dzieci - Adam, kobieta i pierworodny ${ }^{33}$ - Wąż, stają przed ojcem. Widzą siebie tak, jak sądzą, że widzi ich ojciec - jako nagich i przebiegłych. Kobieta i mężczyzna, jak łajane dzieci, opowiadają co zaszło, a niesprawiedliwy, a może tylko przemęczony obowiązkami rodzic, nie wysłuchuje już trzeciego dziecka (węża), zrzucając nań niemal całą winę. Kara jednak, niewspółmierna do popełnionego czynu, dotknie całą „rodzinę". Jahwe - matkujący ojciec i mściwy sędzia, nie może się już później „z twarzą” wycofać z zasądzonego wyroku ${ }^{34}$, lecz już chwilę później z poczuciem winy i nieporadną czułością przyodziewa swe wygnane $\mathrm{z}$ domu, dorastające dzieci w skórzane ubrania ${ }^{35}$.

Pierwsi ludzie cierpią, gdyż różnią się od Jahwe, ale i dlatego, że podejmują szaloną próbę, by różnić się od niego jak najmniej. Ironią jest, że to sam Jahwe podkreśla tę różnicę i przypomina ludziom, że są prochem i w proch mają się obrócić, niejako zapominając, że przed chwilą to on sam właśnie tchnął w proch ziemi życie ${ }^{36}$.

Nie najlepiej układa się również Jahwe z „wnukami” - Kainem i Ablem. Tutaj również na jaw wychodzi jego porywczość i impulsywność. Z zupełnie arbitralnych i niewyjaśnionych przez J powodów Jahwe odrzuca ofiarę Kaina złożoną z płodów ziemi, wypędza go po zabójstwie Abla, a przecież ostatecznie, to właśnie Kain - oracz, wypełniał lepiej od

32 Tamże, s. $194 \mathrm{n}$.

${ }^{33}$ Należy w tym miejscu zaznaczyć, że Bloom sądzi, że Wąż, jako pierwsze stworzenie Jahwe, również należy do jego rodziny. Tamże, s. 190.

34 Tamże, s. 194-199.

35 J. Miles, Bóg. Biografia, s. 48n.

${ }^{36}$ H. Bloom, Ksiega J, s. 196. 
brata klątwę rzuconą w Edenie na Adama („przeklęta niech będzie ziemia $\mathrm{z}$ twego powodu: $\mathrm{w}$ trudzie będziesz zdobywał od niej pożywienie dla siebie" [Rdz 3,17]). Koniec końców, w wyniku boskich wyroków Kain musi przestać wypełniać karę wcześniej zadaną jego ojcu i jest zmuszony radykalnie zmienić tryb życia $\mathrm{z}$ rolniczego na miejski ${ }^{37}$. Potomkom takiego przodka, jakim jest Jahwe, nie jest łatwo sprostać jego sprzecznym i wygórowanym wymaganiom ${ }^{38}$.

Równie skomplikowane stosunki obserwujemy w opisanej przez J historii Noego, Abrama, Izaaka, Jakuba i Józefa. Widzimy, jak stopniowo krąg bliskich Jahwe się rozszerza, jak jego Błogosławieństwo rozciągane jest na kolejne pokolenia, by w końcu, za pośrednictwem Mojżesza objąć cały Naród. J w swej Księdze pokazuje jednak, jak Jahwe kapryśnie i nierówno traktuje swoich „potomków”, jak porzuca Ezawa ${ }^{39}$ pierworodnego Izaaka, jak uśmierca słabych potomków Judy, by następnie wywyższyć jego dzieci z nieprawego łoża ${ }^{40}$, jak w końcu, rozciągnąwszy Przymierze na wszystkich Izraelitów pod Synajem, za chwilę próbuje ich wszystkich uśmiercić, zmieniając ostatecznie wyrok na dożywocie na pustyni ${ }^{41}$. Wbrew teologom i duszpasterzom, nie jest to wzór pedagoga, przyjaciela i rodzica. Ta historia wzajemnych zdrad i powrotów kończy się w końcu zawarciem Przymierza z potomkami Abrama. W ten sposób Jahwe swoim ojcostwem obejmie również Jezusa ${ }^{42}$. Dochodzimy zatem do interesującego nas pytania. Czy Biblia pozwala w ogóle snuć o wiele dalej posunięte spekulacje dotyczące synostwa Bożego Jezusa, włącznie z wszystkim, co w tej materii twierdzi teologia chrześcijańska? Mówiąc inaczej, czy w kontekście Hebrajskiej Biblii, Wcielenie Boga jest w ogóle do pomyślenia?

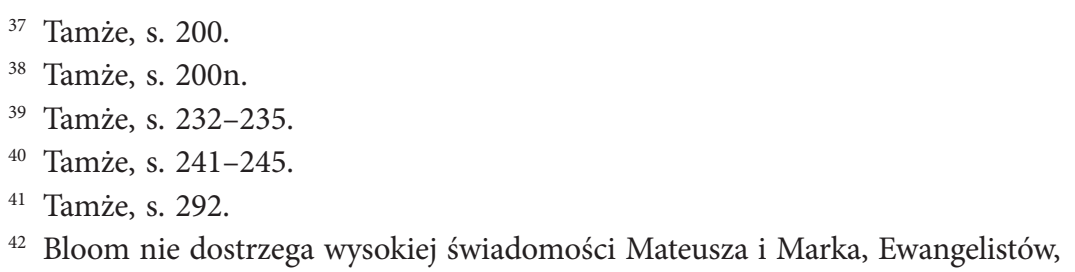
których przecież wysoko nie ceni, a którzy wykazali się niezwykłą wrażliwością, pokazując genealogię Jezusa, wywodząc Jego ród od Abrahama, Judy i Tamar oraz Dawida. Pokazuje to, wbrew zapewnieniom Blooma, łączność duchową opowieści o Jezusie z Jahwe przedstawionym przez J. Por. Mt 1,1-17, Łk 3,23-38. 
Kim jest Jezus Chrystus i czy, a jeśli tak to w jakim sensie jest on Synem Boga? Na pierwsze pytanie można odpowiedzieć analogicznie do odpowiedzi dotyczącej tożsamości Boga Tanachu. Tradycja przekazuje nam wiele, nieprzystających do siebie przekazów. Każda Ewangelia, nawet ograniczając się tylko do kanonicznych ${ }^{43}$, inaczej przedstawia Jezusa. Inaczej widzi Go Paweł, Jakub, później Ojcowie Kościoła. Bloom najradykalniejszą przepaść dostrzega pomiędzy historycznym Jezusem (Jeszuą z Nazaretu) a Chrystusem teologii - Drugą Osobą Trójcy Świętej, podając w wątpliwość związki postaci historycznej z teologicznym abstraktem, za który uważa Chrystusa ${ }^{44}$. Idea Trójcy, centralny dogmat chrześcijaństwa, opiera się na dwóch filarach - jedności Boga Ojca, Syna i Ducha Świętego oraz Wcieleniu Syna ${ }^{45}$. „Wykazanie ojcostwa”, jak dziwacznie by to nie brzmiało w tym kontekście, wydaje się tu sprawą kluczową. Bloom podchodzi do sprawy dwojako. $Z$ jednej strony konfrontuje postać Boga Hebrajskiej Biblii z Jeszuą i Jezusem Chrystusem, z drugiej próbuje podważyć związki Jahwe (jak i każdej odsłony Boga w Tanachu) z Bogiem Ojcem - Pierwszą Osobą chrześcijańskiej Trójcy. Uchwycenie sieci tych skomplikowanych odniesień jest zadaniem złożonym i skomplikowanym, dlatego pozwolę sobie w tym miejscu ograniczyć się jedynie do konfrontacji znanego nam już Jahwe z Księgi J oraz Jezusa Chrystusa.

Pominięcie związków historycznego Jeszui z Jahwe z Księgi J uzasadnia to, że w tym przypadku problem synostwa $\mathrm{w}$ ogóle nie jest postawiony. Jeszua, którego według Blooma nikłe ślady odnajdujemy jedynie w Markowej i Mateuszowej Ewangelii, nie uznaje sam siebie za

${ }^{43}$ Sam Bloom jest wobec pism kanonicznych zdystansowany. Uważa, że żaden z nowotestamentowych autorów, poza może Jakubem Sprawiedliwym, nigdy Jezusa nie spotkał, Ewangelie i listy służą przede wszystkim szerzeniu nienawiści do żydów i ugruntowaniu młodego wówczas chrześcijaństwa. Tenże, Jesus and Yahweh, s. 20-22.

${ }^{44}$ Autor Księgi J niemal całkowitym milczeniem pomija całą tradycję badań nad tzw. problemem Jezusa historycznego. Nie odwołuje się niemal wcale ani do Raimarusa, Alberta Schweitzera, Rudolfa Bultmanna, czy Ernst Käsemann, sięga jedynie pobieżnie do myśli Eda P. Sandersa. Szerzej o tym zagadnieniu G.N. Stanton, Jezus historyczny, [w:] Słownik hermeneutyki biblijnej, R.J. Coggins, J.L. Houlden (red.), Warszawa 2005, s. 348-354.

${ }^{45}$ S.A. Hipp, "Person” in Christian Tradition and the Conception of Saint Albert the Great. A Systematic Study of its Concept as Illuminated by the Mysteries of the Trinity and the Incarnation, Münster 2001, s. 9. 
Boga ani Syna Bożego ${ }^{46}$, nie kwestionuje Prawa i Tradycji Żydowskiej ${ }^{47}$, a o jego Wcieleniu, czy Zmartwychwstaniu w ogóle się nie wspomina ${ }^{48}$. Jeszua jest dzieckiem Boga tylko w tym znaczeniu, w jakim jest nim każdy pobożny żyd, powołujący się na Przymierze zawarte z Abrahamem. Inne znaczenie synostwa, zwłaszcza to implikujące równość z Bogiem i boską naturę, wierny żyd, w tym Jeszua z Nazaretu, musi uznać za bluźnierstwo $^{49}$. Ironią dla Blooma jest to, że ten pobożny, wierny Przymierzu rabin, został przez chrześcijan wykorzystany do stworzenia niechętnej, a nawet wrogiej żydom religii, stanowiącej zawłaszczenie dziedzictwa Biblii hebrajskiej ${ }^{50}$. Interesować będzie nas zatem związek „rodzinny” Jahwe z Jezusem Chrystusem, który oczywiście dla wielu chrześcijan jest również tożsamy z postacią historyczną i jednocześnie jest Drugą Osobą Trójcy, lecz dla Blooma jest jedynie teologicznym abstraktem wysyntetyzowanym z kilku tradycji, zwłaszcza Janowej i Pawłowej ${ }^{51}$.

Tradycyjnie synostwo Boże uzasadnia się w teologii Biblijnymi wypowiedziami samego Jezusa, które ten kieruje do Ojca w Ewangeliach. Chodzi między innymi o określenie $A b b a$, które pojawia się również u Marka (Mk 14,36), czy Modlitwę Pańską, rozpoczynającą się od słów „Ojcze nasz” (Mt 6,9, Łk 11,2). Zdaniem Blooma stwierdzenia te potwierdzają tylko jego pogląd, iż Jezus historyczny czuł się tylko jednym $\mathrm{z}$ wielu synów Boga Izraela ${ }^{52}$. Marek i Mateusz nie twierdzą, że Jezus jest wcielonym Bogiem, ale traktują go jako „spóźnionego proroka” ${ }^{53}$. Bloom dostrzega oczywiście, że w innych źródłach Nowego Testamentu, zwłaszcza

\footnotetext{
${ }^{46}$ H. Bloom, Jesus and Yahweh, s. 97.

47 Tamże, s. 32, 53.

${ }^{48} \mathrm{~W}$ tym miejscu oczywiście Bloom nie może już powołać się wprost na Ewan-
} gelie synoptyczne, jednakże odwołuje się do teorii, wedle której fragment o zmartwychwstaniu w Ewangelii Marka (Mk 16,9-20) został dopisany w późniejszym czasie. Tamże, s. 61. Rzeczywiście fragmentu tego nie znajdziemy w pewnych istotnych świadkach tekstu NT (np. a, B, 304, sys sams armmss)), a ponadto niektórzy Ojcowie Kościoła (Euzebiusz i Hieronim) również o nim nie wspominają. Novum Testamentum Graece et Latine, red. E. Nestle, E. Nestle, K. Aland, B. Aland, Stuttgart 1994, s. 148-149.

\footnotetext{
${ }^{49}$ H. Bloom, Jesus and Yahweh, s. 23.

50 Tamże, s. 72.

51 Tamże, s. 53.

52 Tamże, s. 97.

53 Tamże, s. 152.
} 
u Jana i Pawła, jedność Ojca i Syna jest o wiele mocniej ugruntowana ${ }^{54}$. Właśnie zatem z tymi źródłami, choć sam uznaje je za uzurpację i przejaw lęku przed wpływem ${ }^{55}$, będzie polemizował. Nie odwoła się jednakże do teologii, ale jego polemika będzie opierała się na tym, co można - jak sądzę - nazwać kryteriami filozoficzno-literackimi.

Dlaczego zatem Jezusa nie można uznać za syna Jahwe? Po pierwsze dlatego, że Jezus jest względem Jahwe antytetyczny. Jezus nie ma w sobie niemal nic hebrajskiego, jest w „całości grecki”, to znaczy, postać Chrystusa, tak jak widzimy ją w chrześcijaństwie, została uformowana w duchu filozofii greckiej - w duchu Platona, Arystotelesa, stoików i epikurejczyków ${ }^{56}$. Najlepszym tego dowodem jest idea Wcielenia-Męki-Zmartwychwstania. Jak zauważa Bloom, w judaizmie obecne jest myślenie o Bogu, który wycofuje się ze świata, czy jest, jak mówi Buber, „zaćmiony”, ale samobójstwo Boga jest w obrębie tej religii nie do pomyślenia ${ }^{57}$.

Jahwe, biorąc pod uwagę jego przedstawioną w Biblii, zwłaszcza Księdze J psychologiczną charakterystykę, zwyczajnie nie może wcielić się w Osobę Chrystusa, gdyż samobójstwo, jak określa ukrzyżowanie Bloom, zwyczajnie nie pasuje do tego, co o Jahwe wiemy. Interpretacja domagająca się jedności Nowego Testamentu i Tanachu zwyczajnie zamienia w groteskę i farsę opowieść J o Jahwe ${ }^{58}$.

Antytetyczność teologicznego Jezusa i Jahwe przejawia się również $\mathrm{w}$ tym, że Jezus jest bogiem śmierci i bogiem umarłych, podczas gdy Jahwe jest Bogiem życia - stwarza życie, podtrzymuje je i rozdziela Bło-

${ }^{54}$ Tamże, s. 145, 148n. Warto w tym miejscu, przynajmniej w wielkim skrócie, przedstawić kontrargumenty, które można wysunąć przeciwko Bloomowi. Teologia katolicka przyjmuje, że termin „syn Boży” w Biblii przysługiwać może Jezusowi na dwa sposoby. Tytuł ten w Starym Testamencie jest nadawany aniołom, członkom ludu wybranego, królom Izraela. W tym sensie Nowy Testament, posługując się tym tytułem, niekoniecznie sugeruje, by był on kimś więcej niż tylko człowiekiem, Katechizm Kościoła Katolickiego, Poznań 1994, 441 (dalej KKK). Jednakże NT używa tego tytułu również w inny, uroczysty sposób w wielu miejscach (np. Ga 1,15-16, 1 Tes 1,10, Dz 9,20, Łk 22,70, J 3,18; 10,30; 15,1-27 oraz wielu innych, także w Ewangelii Mateuszowej, którą Bloom uznaje za wolną od tej interpretacji Mt 15,39; 16,16-17; 3,17; 17,5).

${ }^{55} \mathrm{H}$. Bloom, Jesus and Yahweh, s. 47, 112.

56 Tamże, s. 24.

${ }^{57} \mathrm{H}$. Bloom, A. Bielik-Robson, Judeochrześcijaństwo to mit.

${ }^{58}$ Tenże, Jesus and Yahweh, s. 148n. 
gosławieństwo, które oznacza zawsze „więcej życia”. Misja Jezusa polega na pokonaniu śmierci, wiąże się z Jego własną męką i śmiercią. Jezus wskrzesza umarłych (J 11,1-44; Łk 8,49-59), Jahwe bierze do siebie żywych Henocha $(\operatorname{Rdz} 5,24)$ i Eliasza $(2 \operatorname{Kr} 2,11)^{59}$.

Jezus Chrystus jest w końcu Bogiem miłości. Mesjasz chrześcijan kocha ludzkość i gotowy jest za nią cierpieć i umrzeć. Kocha też Ojca, przedziwną tajemniczą miłością, która ma charakter osobowy, tak, że sama staje się Trzecią Osobą Trójcy - Duchem Świętym ${ }^{60}$. O Jahwe czegoś takiego nie można powiedzieć. W Torze zresztą miłość taka nie jest wymagana. Dla wiernego żyda, jak chociażby dla Jeszui z Nazaretu miłość Boga to codzienne przestrzeganie przykazań, nieoszukiwanie na wadze, zostawianie części plonu dla ubogich. Nic z mistycznej miłości transcendentnego obiektu, którą Jezus miłuje Ojca w Ewangelii Jana ${ }^{61}$. Miłość Jahwe, jeśli w ogóle można o niej mówić, to miłość zazdrosna i kapryśna ${ }^{62}$, a nade wszystko odwoływalna ${ }^{63}$. Deklaracje miłości składane przez Jahwe Dawidowi brzmią w uszach Blooma fałszywie, cóż dopiero powiedzieć o tych składanych Jezusowi na Górze Przemienienia ${ }^{64}$ ? Bloom stwierdzi, że jeśli Jahwe potrafi kochać, to jest to miłość taka, jaką darzy Szekspirowski Król Lear swą Cordelię - zapalczywa czułość, nic więcej. Transcendentny Ojciec, tym bardziej wydaje się niezdolny do miłości. Dlatego stwierdzenie „Bóg jest miłością” w świetle Biblii jest dla Blooma pozbawione elementarnego sensu65. Jahwe Księgi J nie potrafi kochać również z tego powodu, że w przeciwieństwie do Jezusa i późniejszych ujęć Boga Izraela, ma tu Bloom na myśli Pieśń nad Pieśniami, czy Kabałę, Jahwe jest totalnie pozbawiony aspektu seksualnego ${ }^{66}$. Podsumowując problem miłości Jahwe do ludu, Bloom spyta retorycznie: co byś powiedział, wyznawszy miłość jakiejś osobie, gdybyś w zamian usłyszał „współczuję

\footnotetext{
59 Tamże, s. 153.

60 Augustyn, O Trójcy Świętej, tłum. M. Stokowska, Kraków 1996, s. 507.

${ }^{61}$ H. Bloom, Jesus and Yahweh, s. 163n.

62 Tenże, Księga J, s. 293.

63 Tenże, Jesus and Yahweh, s. 165.

64 Tamże, s. 166.

65 Tamże, s. 168.

66 Tamże, s. 220.
} 
ci"? ${ }^{67}$ Czy ta miłość ma coś wspólnego z miłością, którą chrześcijanie zawsze przypisywali swojemu Bogu? Odrzucenie miłości Jahwe oznacza dla chrześcijaństwa podważenie dwóch centralnych dogmatów - Wcielenia, którego motywacją musiałaby być miłość ${ }^{68}$ oraz dogmatu o Trójcy świętej, której zasadą jest miłość między boskimi Osobami ${ }^{69}$.

Biorąc pod uwagę wszystko, co powiedzieliśmy dotąd o Jahwe i o tym, jak traktuje on swoich najbliższych, trzeba stwierdzić, że jeśli Jezus Chrystus uważał się rzeczywiście za jego syna, to jego postawa wobec ojca i ofiara, którą złożył sam z siebie, była wyrazem nie tylko synowskiej nadgorliwości, ale graniczyła niemal z szaleństwem. Jahwe jest zupełnie nieobliczalny, czasami pojawia się w najmniej oczekiwanych momentach, innym razem nie ma go, gdy jest najbardziej potrzebny. Sam Jahwe zaś uważa, że ma prawo wymagać zdumiewających dowodów miłości, co zwykle charakteryzuje bardzo złych ojców ${ }^{70}$. Nie wiadomo, czy przyjmie z radością składany mu dar czy ofiarę, czy też kapryśnie ją odrzuci, a może nawet, jak w przypadku Kaina, zapała gniewem i wymierzy karę. Stąd decyzja Chrystusa poprzedzająca ofiarę Krzyżową powinna być odczytana nie tylko jako heroiczna, lecz także jako ryzykowna, a nawet szalona ${ }^{71}$.

Oczywiście nie jest powiedziane, że owa antytetyczność Jahwe i Jezusa wykluczają pokrewieństwo - Freud, do którego Bloom dość chętnie się odwołuje, mówi raczej o konflikcie i niepodobieństwie między ojcami a synami ${ }^{72}$, ale zdaniem Blooma dogmat o Trójcy, zakładający jedność Osób, jest w perspektywie jego literackich badań Biblii nie do utrzymania.

Myśl, że Jezus miałby być mimo wszystko synem Jahwe, kłóci się z literackim wyczuciem Blooma. W wysokiej klasy literaturze takie kiczowate połączenia dwóch, istniejących w jakichś równoległych i nieprzystających do siebie światach osób - ojca i syna, zwyczajnie nie powinno się zdarzyćc ${ }^{73}$. Czy można jednak uznać to za rozstrzygający argument w kwestii synostwa bożego Chrystusa? Być może rzeczywiście, teologia,

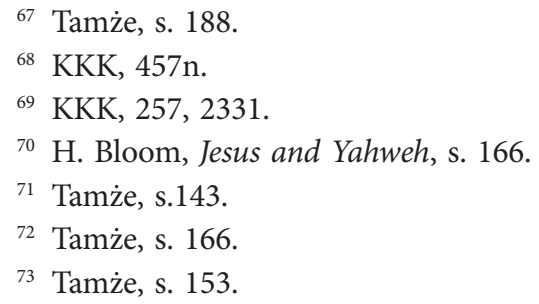


jak mawia Bloom, jest bardzo kiepską literaturą ${ }^{74}$, ale jak sądzę nie można za pomocą estetycznego kryterium rozstrzygnąć sporu o naturę relacji Syna i Ojca w Trójcy oraz pytania o Wcielenie Boga.

\section{PODSUMOWANIE}

Interpretacja Biblii Blooma zmierza zatem do uzasadnienia jego tezy, że tradycja chrześcijańska, która odwołuje się do Tory i pozostałych ksiąg, które nazywa Starym Testamentem, jest nieuzasadniona, że Nowy Testament jest próbą zawłaszczenia sobie dziedzictwa innej kultury, że jest tym, co sam Bloom nazywa uzurpacją i przejawem lęku przed wpływem ${ }^{75}$. $\mathrm{Z}$ tej pozornie ograniczającej swój zasięg do literaturoznawstwa uwagi Bloom wyciąga jednak bardzo daleko idące wnioski. Uważa mianowicie, że koncepcja kultury judeochrześcijańskiej jest jedynie wygodnym i użytecznym konstruktem, który umożliwia zachowanie pozorów dialogu międzykulturowego. W rzeczywistości pomiędzy judaizmem i Żydami w ogóle a chrześcijaństwem zieje nieprzekraczalna przepaść niezrozumienia, ukrytej, bądź jawnej wrogości i nienawiści ${ }^{76}$. Choć sam nie uznaje się za wyznawcę żadnej religii, Bloom zdecydowanie swą interpretacją oskarża przede wszystkim chrześcijaństwo, jako nienawistne, wtórne i, co dla niego najważniejsze, kiczowate. $\mathrm{Z}$ analiz Blooma wynika zatem, że punktem kulturowego rozłamu jest stosunek do Wcielenia, które jest dla niego skandalem w nowym, pozateologicznym znaczeniu - jest skandalem estetycznym, artystyczną perwersją i profanację jednej z najwspanialszych książek stworzonych przez ludzkość - Księgi J.

Paradoksalnie jednak, wbrew intencjom Blooma, w jego analizach to właśnie Wcielenie jawi się jako idea centralna dla naszej kultury, idea niezrozumiała, skandaliczna i tajemnicza, sama wymykająca się interpretacjom, ale warunkująca inne interpretacje. To skłania mnie do określenia Wcielenia, „nie-miejscem” hermeneutycznym, osią interpretacji naszej kultury, która sama jednak zawsze pozostaje niewidoczna i nieuchwytna

\footnotetext{
74 Tamże, s. 98.

75 Tamże, s. 47, 112.

${ }^{76}$ H. Bloom, A. Bielik-Robson, Judeochrześcijaństwo to mit.
} 
pojęciowo. Jest ono miejscem atopicznym - „poza rozumieniem”, elementem narracji, który rozbija spójność tekstu, zmuszając czytelnika do wysiłku myślenia. Wcielenie zatem rozbija wszelki pozorny dialog, relatywizującą ekumeniczność, choć niedostępne i niewyjaśnialne, natarczywie domaga się podejmowania kolejnych prób interpretacji ${ }^{77}$. Odrzucenie tej kategorii czy też pomniejszania jej roli, jak również krytyka Nowego Testamentu i chrześcijańskiej tradycji, dokonana przez Blooma, wydaje się również przejawem lęku przed wpływem, o którym sam tak chętnie mówi w swoich pracach.

\section{BIBLIOGRAFIA}

Augustyn, O Trójcy Świętej, tłum. M. Stokowska, Kraków 1996.

Benedykt XVI, Jezus $z$ Nazaretu: od wjazdu do Jerozolimy do zmartwychwstania, thum. W. Szymona, Kraków 2019.

Benedykt XVI, Jezus $z$ Nazaretu: od chrztu w Jordanie do Przemienienia, tłum. W. Szymona, Kraków 2017.

Bloom H., Jesus and Yahweh: the names divine, New York 2005.

Bloom H., Ksiegga J, tłum. B. Baran, Warszawa 2018.

Bloom H., Bielik-Robson A., Judeochrześcijaństwo to mit, „Dziennik - wydanie internetowe" 5.11.2007, https://wiadomosci.dziennik.pl/wydarzenia/artykuly/183928,judeochrzescijanstwo-to-mit.html (dostęp 8.05.2019).

Bruckberger R.L., Dzieje Jezusa Chrystusa, tłum. M. Ponińska, Warszawa 1970.

Di Cesare D., Átopos. Hermeneutyka i miejsce poza rozumieniem, tłum. A Przyłębski, [w:] Dziedzictwo Gadamera, red. A. Przyłębski, Poznań 2004, s. 61-69.

Hipp S.A., „Person” in Christian Tradition and the Conception of Saint Albert the Great. A Systematic Study of its Concept as Illuminated by the Mysteries of the Trinity and the Incarnation, Münster 2001.

Johnson P., A history of the Jews, New York 2006.

Jung C.G., Odpowiedź Hiobowi, Warszawa 1995.

Katechizm Kościoła Katolickiego, Poznań 1994.

Kruger M.J., The Question of Canon: Challenging the Status Quo in the New Testament Debate, Downers Grove 2013.

Novum Testamentum Graece et Latine, red. E. Nestle, E. Nestle, K. Aland, B. Aland, Stuttgart 1994.

77 D. di Cesare, Átopos. Hermeneutyka i miejsce poza rozumieniem, tłum. A Przyłębski, [w:] Dziedzictwo Gadamera, red. A. Przyłębski, Poznań 2004, s. 65n. 
Metzger M., The canon of the New Testament: its origin, development, and significance, Oxford-New York 1987.

Miles J., Bóg: biografia, Warszawa 1998.

Newman R.C., The Council of Jamnia and the Old Testament Canon, „Westminster Theological Journal”, t. 38, nr 4(1976) nr 38, s. 319-348.

Pismo Święte Starego i Nowego Testamentu, w przekładzie z języków oryginalnych, Poznań 1991.

Słownik hermeneutyki biblijnej, red. R. J. Coggins, J. L. Houlden, Warszawa 2005.

Thielicke H., Der Evangelische Glaube, Bd. 2: Gotteslehre und Christologie, Tübingen 1973. 